\section{Effect of Fertilizer Source on Water Use of St. Augustinegrass and Ornamental Plants}

\author{
Subhrajit K. Saha and Laurie E. Trenholm ${ }^{1}$ \\ Environmental Horticulture Department, University of Florida, P.O. Box \\ 110675, Gainesville, FL 32611
}

\section{J. Bryan Unruh \\ West Florida Research and Education Center, University of Florida, Jay, FL 32565}

\section{Additional index words. Canna generalis, Ligustrum japonicum, Nandina domestica,} Allamanda cathartica, fertilizer

\begin{abstract}
Due to increasing consumption of water in landscapes and concern over conservation of water resources, this study was conducted to determine the effect of fertilizer source on water consumption of turf and ornamentals and to compare total water use (WU) of st. augustinegrass and ornamentals. The experiment was performed in a climate-controlled greenhouse at the G.C. Horn Turfgrass Field Laboratory at the University of Florida in Gainesville. 'Floratam' st. augustinegrass (Stenotaphrum secundatum Walt. Kuntze) was compared to a mix of common Florida ornamentals including canna (Canna generalis L.H. Bailey), nandina (Nandina domestica Thunb.), ligustrum (Ligustrum japonicum Thunb.), and allamanda (Allamanda cathartica L.). All plants were grown in 300-L plastic pots in Arredondo fine sand. There were three fertilizer treatments [quick-release fertilizers (QRF) 16-4-8 and 15-0-15, and slow-release fertilizer (SRF) 8-4-12] applied at $4.9 \mathrm{~g} \mathrm{~N} / \mathrm{m}^{2}$ every 60 days. Water was applied as needed to maintain turgor and turfgrass pots were mowed weekly. Experimental design was a randomized complete block design with four replications. Visual quality ratings and time domain reflectometry (TDR) data were collected weekly. Both turf and ornamentals consumed less water and had higher water use efficiency (WUE) when treated with SRF. Ornamentals consumed from $11 \%$ to $83 \%$ more water than turf, depending on season. These results may have implications in future research on irrigation management to verify WUE between turf and ornamentals in an urban landscape.
\end{abstract}

Water use (WU) in home landscapes is under increasing scrutiny due to population growth. Turfgrass is often cited as a high water user in the landscape, and in some cases, there has been legislation limiting turf use in landscapes. Cultural factors have been shown to influence turfgrass WU and evapotranspiration (ET). Feldhake etal.(1983)reported that turfreceiving monthly Napplications throughout the growing season used $13 \%$ more water than turf receiving one fertilizer application for the year.

Water lost via ET also depends on environmental, morphological, and anatomical factors. Environmental factors include relative humidity (Carrow, 1995; Nonami and Boyer, 1990), wind speed, soil moisture, and shade (Takakura et al., 2000). Morphological factors include leaf pubescence and degree of cuticular wax present on the leaves (Peacock and Dudeck, 1984). Plant water consumption may also depend on anatomical factors such as leaf area index, leaf orientation, and texture (Ebdon and Petrovic, 1998), and shoot density (Kim and Beard, 1988). Higher turfgrass ET rates were found to be associated with increased shoot density (Biran

Received for publication 29 June 2005. Accepted for publication 19 Aug. 2005. Florida Agricultural Experiment Station journal series.

${ }^{1}$ To whom reprint requests should be addressed; e-mail1trenholm@ifas.ufl.edu. water use efficiency (WUE). WUE may be defined in various ways, including ratio of biomass produced per unit of water used or as the measure of photosynthesis per volume of water consumed. In a mixed sward of orchardgrass (Dactylis glomerata L.), creeping red fescue (Festuca rubra L.), and bromegrass [Bromus inermis (Leyss.) Lindm.], Krogman (1967) observed that up to a certain level of crop growth, factors that promoted growth, such as N, also promoted WUE. Christians (1998) noted that higher $\mathrm{N}$ use might decrease WUE in grasses.

In perennial landscape plants, irrigation management is critical for conservation of water and for the health of the plants, but limited information is available about effects of fertilizer source on WUE. Turf and ornamentals coexist in the landscape and generally receive similar fertilization and irrigation regimes, which may actually increase plant WU. Therefore, the objectives of this study were to determine the effect of fertilizer source on WU and WUE and to compare WU of st. augustinegrass and ornamentals.

\section{Materials and Methods}

The research was performed in a climatecontrolled greenhouse at the G.C. Horn Memorial Turfgrass Field Laboratory at the University of Florida in Gainesville. 'Floratam' st. augustinegrass and a combination of ornamentals that included Canna generalis, Ligustrum japonicum 'Lake Tresca', Nandina domestica 'Harbor Dwarf', and Allamanda cathartica were established in large plastic pots in May 2002. The pots measured $0.8 \mathrm{~m}$ in diameter $\times 0.4 \mathrm{~m}$ tall with a volume of $300 \mathrm{~L}$.

Pots were placed on reinforced metal tables in the greenhouse. Gravel $(5 \mathrm{~cm})$ was placed at the bottom of each pot, and a mesh cloth was placed over the gravel to retain the media. Pots were filled with Arredondo fine sand (loamy, siliceous, hypothermic, Grossarenic Paleudalt). Mature st. augustinegrass sod was harvested from a research field and planted to fully cover the container. Ornamental plants grown in 2.8-L containers were acquired from a retail nursery. One of each species was planted in the ornamental treatment pots. Cypress mulch was applied to the soil surface of ornamental pots at a depth of $2.5 \mathrm{~cm}$. Plants were allowed to establish for a 2-month period before treatments began.

Three fertilizer treatments were used: quick-release fertilizer (QRF) 16-4-8 (ammonium sulfate, concentrated superphosphate, and potassium chloride), QRF 15-0-15 (am-

Table 1. Irrigation schedule (L) in six fertilizer cycles (FCs).

\begin{tabular}{lcrrr}
\hline & \multicolumn{3}{c}{ Water applied $^{\mathrm{z}}$} \\
\cline { 2 - 5 } FC & WF & $\mathrm{IW}_{1}$ & $\mathrm{IW}_{2}$ & $\mathrm{IW}_{3}$ \\
\hline First FC (July to September) & 4 & 16 & 12 & 24 \\
Second FC (September to November) & 4 & 16 & 10 & 12 \\
Third FC (November to Januray) & 4 & 8 & 8 & 12 \\
Fourth FC (Januray to March) & 4 & 9 & 8 & 12 \\
Fifth FC (March to May) & 4 & 20 & 9 & 38 \\
Sixth FC (May to July) & 4 & 20 & 40 \\
\hline
\end{tabular}

${ }^{2} \mathrm{WF}=$ water applied with fertilizer, IW $=$ water applied before first leaching event, IW $=$ water applied between first and second leaching event, and $\mathrm{IW}_{3}=$ water applied between second and third leaching event. 
Table 2. Effects of fertilizer source on water consumption (L) of st. augustinegrass in six fertilizer cycles (FCs).

\begin{tabular}{|c|c|c|c|c|c|c|c|}
\hline Fertilizer & $\begin{array}{c}\text { FC } 1 \\
\text { July to September }\end{array}$ & $\begin{array}{c}\text { FC } 2 \\
\text { September to November }\end{array}$ & $\begin{array}{c}\text { FC } 3 \\
\text { November to Januray }\end{array}$ & $\begin{array}{c}\text { FC } 4 \\
\text { Januray to March }\end{array}$ & $\begin{array}{c}\text { FC } 5 \\
\text { March to May }\end{array}$ & $\begin{array}{c}\text { FC } 6 \\
\text { May to July }\end{array}$ & $\begin{array}{c}\text { Avg } \\
\text { July to July }\end{array}$ \\
\hline QRF 15-0-15 & $105.9 \mathrm{a}^{\mathrm{z}}$ & $88.1 \mathrm{a}$ & $70.6 \mathrm{a}$ & $68.7 \mathrm{a}$ & $116.1 \mathrm{a}$ & $136.4 \mathrm{a}$ & $97.7 \mathrm{a}$ \\
\hline QRF 16-4-8 & $101.7 \mathrm{ab}$ & $86.4 \mathrm{a}$ & $71.7 \mathrm{a}$ & $64.8 \mathrm{a}$ & $119.3 \mathrm{a}$ & $140.3 \mathrm{a}$ & $97.3 \mathrm{a}$ \\
\hline SRF 8-4-12 & $94.1 \mathrm{~b}$ & $79.2 \mathrm{a}$ & $65.2 \mathrm{a}$ & $60.1 \mathrm{a}$ & $112.4 \mathrm{~b}$ & $132.1 \mathrm{a}$ & $90.5 \mathrm{a}$ \\
\hline$P$ value & 0.08 & NS & NS & NS & 0.009 & NS & NS \\
\hline
\end{tabular}

${ }^{\mathrm{z}}$ Means followed by the same letter do not differ significantly at $P<0.05$.

NS Nonsignificant.

Table 3. Effects of fertilizer source on water consumption (L) of ornamentals ${ }^{\mathrm{z}}$ in six fertilizer cycles (FCs).

\begin{tabular}{|c|c|c|c|c|c|c|c|}
\hline Fertilizer & $\begin{array}{c}\text { FC } 1 \\
\text { July to September }\end{array}$ & $\begin{array}{c}\text { FC } 2 \\
\text { September to November }\end{array}$ & $\begin{array}{c}\text { FC } 3 \\
\text { November to Januray }\end{array}$ & $\begin{array}{c}\text { FC } 4 \\
\text { Januray to March }\end{array}$ & $\begin{array}{c}\text { FC } 5 \\
\text { March to May }\end{array}$ & $\begin{array}{c}\text { FC } 6 \\
\text { May to July }\end{array}$ & $\begin{array}{l}\text { Avg } \\
\text { July to July }\end{array}$ \\
\hline$\overline{\text { QRF } 15-0-15}$ & $116.0 \mathrm{a}^{\mathrm{y}}$ & $126.2 \mathrm{a}$ & $110.2 \mathrm{a}$ & $124.7 \mathrm{a}$ & $166.3 \mathrm{a}$ & $181.4 \mathrm{a}$ & $137.5 \mathrm{a}$ \\
\hline QRF 16-4-8 & $113.6 \mathrm{a}$ & $122.0 \mathrm{ab}$ & $108.2 \mathrm{a}$ & $128.5 \mathrm{a}$ & $164.5 \mathrm{a}$ & $184.5 \mathrm{a}$ & $136.9 \mathrm{a}$ \\
\hline SRF 8-4-12 & $106.5 \mathrm{a}$ & $114.9 \mathrm{~b}$ & $98.2 \mathrm{~b}$ & $100.4 \mathrm{~b}$ & $140.7 \mathrm{~b}$ & $168.0 \mathrm{~b}$ & $121.4 \mathrm{a}$ \\
\hline$P$ value & NS & 0.03 & 0.008 & 0.009 & 0.04 & 0.03 & NS \\
\hline
\end{tabular}

${ }^{z}$ Ornamentals included Canna generalis, Ligustrum japonicum, Nandina domestica, and Allamanda cathartica.

${ }^{\mathrm{y}}$ Means followed by the same letter do not differ significantly at $P<0.05$.

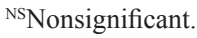

monium sulfate and potassium chloride), and a slow-release fertilizer (SRF) 8-4-12 (polymer-coated sulfur-coated urea, ammonium phosphate, and polymer-coated potassium sulfate). Treatments were applied six times at 2-month intervals (17 July, 19 Sept., and 20 Nov. 2002 and 17 Jan., 18 Mar., and 21 May 2003 ) at a rate of $4.9 \mathrm{~g} \mathrm{~N} / \mathrm{m}^{2}$ to both turf and ornamentals. Each of these 2-month periods is referred to as one fertilizer cycle (FC).

Irrigation schedules varied by season, with the same irrigation rates applied to both turf and ornamentals (Table 1). Leaching events were conducted three times over the course of the FC to ensure adequate sample for analysis of nitrates and phosphates from the leachate. WU values were derived from the following equation: $\mathrm{WU}=\mathrm{WF}+\left(\mathrm{IW}_{1}+\mathrm{WU}_{1}\right)+\left(\mathrm{IW}_{2}+\right.$ $\left.\mathrm{WU}_{2}\right)+\left(\mathrm{IW}_{3}+\mathrm{WU}_{3}\right)$, where $\mathrm{WF}=$ water applied with fertilizer $(4 \mathrm{~L})$; IW $\mathrm{IW}_{1}=$ water applied before first leaching event, excluding WF; $\mathrm{IW}_{2}=$ water applied between first and second leaching event; $\mathrm{IW}_{3}=$ water applied between second and third leaching event; $\mathrm{WU}_{\mathrm{n}}=\mathrm{WA}_{\mathrm{n}}$ - WL, where $\mathrm{n}=$ leaching event number $(\mathrm{n}$ $=1,2,3) ; \mathrm{WA}_{\mathrm{n}}=$ water applied to a pot on a leaching event; and $\mathrm{WL}_{\mathrm{n}}=$ water leached from a pot on a leaching event.

WUE was measured as biomass production per unit water applied. Roots and shoots were dried and weighed for root WUE (WUE $\left.\mathrm{R}_{\mathrm{R}}\right)$ and shoot WUE (WUE ${ }_{\mathrm{S}}$ ). Total WUE (WUE ${ }_{\mathrm{T}}$ ) was calculated as the sum of root and shoot mass. These measurements were taken at termination of the experiment and analyzed to determine WUE over the year and during FC 6 (May to July 2003)

Turf was mowed every week with hand-held clippers at a height of $9 \mathrm{~cm}$. Clippings were removed. A micronutrient blend (STEP, The Scotts Co., Marysville, Ohio) was applied at a rate of $6.7 \mathrm{~g} \cdot \mathrm{m}^{-2}$ in September 2002 to both turf and ornamentals. Bifenthrin was applied to the turf at a rate of $4 \mathrm{~g} \cdot \mathrm{L}^{-1}$ to control a minor infestation of armyworm (Spodoptera spp.). Ligustrums were treated with $2 \%$ insecticide oil during November 2002 to control a scale (Hemiberlesia lataniae) infestation. Greenhouse temperature was monitored using a temperature datalogger (Hobo; Onset
Computer Corp., Bourne, Mass.) and light intensity at different canopy levels was measured weekly with a quantum sensor (LI-250; LI-COR, Inc., Lincoln, Neb.). At termination of the experiment, shoots and roots from each pot were harvested and dried for 24 hours at $75{ }^{\circ} \mathrm{C}$. Ornamental roots were excavated and washed but were not separated by plant species due to the intermingling of roots.

Experimental design was a randomized complete block model with four replications. Data were analyzed with the SAS analytical program(SAS institute, Inc. 2003) to determine treatment differences at $P<0.05$. Means were separated with Fisher's LSD.

\section{Results and Discussion}

Effect of fertilizer on WU of st. augustinegrass and ornamentals. Averaged over the year, there were no differences in st. augustinegrass

Table 4. Water use efficiency (WUE) of st. augustinegrass and ornamentals $\mathrm{s}^{\mathrm{z}}$ measured $\left(\mathrm{g} \cdot \mathrm{L}^{-1}\right)$ during fertilizer cycle (FC) 6 (May to July) and averaged over the year.

\begin{tabular}{|c|c|c|c|c|c|c|}
\hline \multirow[b]{2}{*}{ Fertilizer } & \multicolumn{3}{|c|}{ FC 6 (May to July) } & \multicolumn{3}{|c|}{ Averaged yearly } \\
\hline & $\mathrm{WUE}_{\text {Shoot }}$ & WUE $_{\text {Root }}$ & $\overline{\text { WUE }_{\text {Total }}}$ & WUE $_{\text {Shoot }}$ & WUE $_{\text {Root }}$ & WUE $_{\text {Total }}$ \\
\hline \multicolumn{7}{|l|}{ Turfgrass } \\
\hline QRF $15-0-15$ & $7.9 \mathrm{a}^{\mathrm{y}}$ & $1.2 \mathrm{a}$ & $9.1 \mathrm{a}$ & $11.1 \mathrm{a}$ & $1.7 \mathrm{a}$ & $12.7 \mathrm{a}$ \\
\hline QRF 16-4-8 & $7.6 \mathrm{a}$ & $1.2 \mathrm{a}$ & $8.8 \mathrm{a}$ & $11.0 \mathrm{a}$ & $1.7 \mathrm{a}$ & $12.7 \mathrm{a}$ \\
\hline SRF 8-4-12 & $6.5 \mathrm{~b}$ & $1.1 \mathrm{a}$ & $7.6 \mathrm{~b}$ & $9.5 \mathrm{a}$ & $1.5 \mathrm{a}$ & $11.1 \mathrm{a}$ \\
\hline$P$ value & 0.02 & NS & 0.01 & NS & NS & NS \\
\hline \multicolumn{7}{|l|}{ Ornamental } \\
\hline QRF $15-0-15$ & $3.7 \mathrm{a}^{\mathrm{y}}$ & $10.3 \mathrm{a}$ & $13.9 \mathrm{a}$ & $4.8 \mathrm{a}$ & $13.6 \mathrm{a}$ & $18.4 \mathrm{a}$ \\
\hline QRF 16-4-8 & $3.7 \mathrm{a}$ & $9.9 \mathrm{a}$ & $13.7 \mathrm{a}$ & $4.9 \mathrm{a}$ & $13.4 \mathrm{a}$ & $18.4 \mathrm{a}$ \\
\hline SRF 8-4-12 & $2.8 \mathrm{~b}$ & $8.6 \mathrm{a}$ & $11.5 \mathrm{a}$ & $3.9 \mathrm{a}$ & $12.1 \mathrm{a}$ & $16.0 \mathrm{a}$ \\
\hline$P$ value & 0.04 & NS & NS & NS & NS & NS \\
\hline
\end{tabular}

${ }^{{ }^{2} \text { Ornamentals included Canna generalis, Ligustrum japonicum, Nandina domestica, and Allamanda }}$ cathartica.

${ }^{y}$ Means followed by the same letter do not differ significantly at $P<0.05$.

NSNonsignificant.

Table 5. Comparison of water use efficiency (WUE) of st. augustinegrass and ornamentals $\left(g \cdot \mathrm{L}^{-1}\right)$ in fertilizer cycle (FC) 6 and over the year.

\begin{tabular}{llcccccc}
\hline & \multicolumn{3}{c}{ FC 6 (May to July) } & & \multicolumn{3}{c}{ Averaged yearly } \\
\cline { 2 - 4 } Fertilizer & WUE $_{\text {Shoot }}$ & WUE $_{\text {Root }}$ & WUE $_{\text {Total }}$ & & WUE $_{\text {Shoot }}$ & WUE $_{\text {Root }}$ & WUE $_{\text {Total }}$ \\
\hline Turf & $7.4 \mathrm{a}^{\mathrm{y}}$ & $1.1 \mathrm{~b}$ & $8.6 \mathrm{~b}$ & & $10.5 \mathrm{a}$ & $1.6 \mathrm{~b}$ & $12.2 \mathrm{~b}$ \\
Ornamentals & $3.4 \mathrm{~b}$ & $9.6 \mathrm{a}$ & $13.0 \mathrm{a}$ & & $4.6 \mathrm{~b}$ & $13.0 \mathrm{a}$ & $17.6 \mathrm{a}$ \\
$P$ value & 0.0001 & 0.0001 & 0.0001 & & 0.0001 & 0.0001 & 0.0003 \\
\hline
\end{tabular}

${ }^{2}$ Ornamentals included Canna generalis, Ligustrum japonicum, Nandina domestica, and Allamanda cathartica.

${ }^{y}$ Means followed by the same letter do not differ significantly at $P>0.05$. 


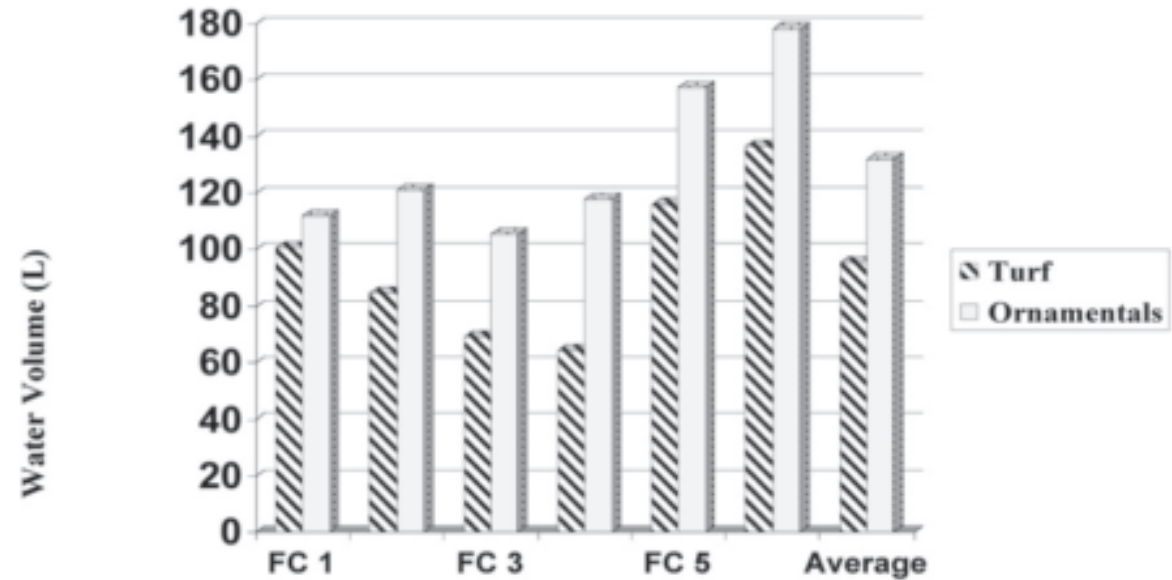

Fig. 1. Water use of turf and ornamentals over six fertilizer cycles and averaged over the year. Means differed significantly $(P=0.05)$ between turf and ornamentals for all cycles.

plants (data not presented), suggesting that increased shoot growth is correlated with water consumption. This is in contrast to results of Broschat (1995), who observed less biomass production in Spathyphyllum treated with QRF as compared to SRF.

Effect of fertilizer on WUE. Turf treated with QRF had higher $\mathrm{WUE}_{\mathrm{T}}$ and $\mathrm{WUE}_{\mathrm{S}}$ in FC 6 (Table 4), but no differences were observed when WU was averaged over the year. Similarly, QRF treated ornamentals had higher WUE $_{\mathrm{S}}$ in FC 6 (Table4), but no differences were found when WU was averaged over the year.

Shoot $\mathrm{WUE}_{\mathrm{S}}$ was higher in st. augustinegrass than in ornamentals both in FC 6 and when averaged over the entire year (Table 5). This was in contrast to $\mathrm{WUE}_{\mathrm{R}}$ and $\mathrm{WUE}_{\mathrm{T}}$, both of which were higher in ornamentals than in st. augustinegrass during FC 6 and when averaged over the entire year (Table 5). The $\mathrm{WUE}_{\mathrm{S}}$ of turf is not surprising, since turfgrass growth increases rapidly in response to water as compared to ornamentals. However, root production in mature ornamentals is greater than in turf(Gibbens and Lenz, 2001), resulting in greater $\mathrm{WUE}_{\mathrm{R}}$ and $\mathrm{WUE}_{\mathrm{T}}$ in ornamentals.

Comparison of water consumption byst. augustinegrass and ornamentals. In all fertilizer cycles, st. augustinegrass consumed less water than ornamentals (Fig. 1). WU of ornamentals during fertilizer cycles ranged from $11 \%$ to $83 \%$ more than turf. Averaged over the year, water consumption of ornamentals was 39\% more than in turf. Results may differ in a landscape setting, where ornamentals are not space bound and can forage more deeply for water.

Minimal differences in WU between plant types occurred during FC 1 (July to September). This cycle was part of the establishment period, during which time ornamentals had less shoot and root mass and therefore used less water than when mature. Greater differences in water consumption were found in $\mathrm{FCs}$ 3 and 4 (November to mid-March), when st. augustinegrass was in a somewhat dormant state as compared to ornamentals. Canna was the only ornamental that went dormant, which was noted by senescent foliage. The lack of dormancy in the remaining ornamentals resulted in higher WU of ornamentals as compared to st. augustinegrass during winter months.

\section{Conclusions}

Both st. augustinegrass and ornamentals consumed less water when treated with SRF, particularly during establishment or times of optimal growth. Higher $\mathrm{WUE}_{\mathrm{S}}$ and $\mathrm{WUE}_{\mathrm{T}}$ occurred in turf treated with QRF in FC 6, with no differences when averaged over the year. Ornamentals had greater $\mathrm{WUE}_{\mathrm{S}}$ when treated with QRF.

Results showed that, on average, ornamentals consumed $39 \%$ more water than st. augustinegrass, which varied from $11 \%$ to as high as $83 \%$, depending on the season. The greatest difference in water consumption was found during winter, when st. augustinegrass remained semi-dormant and ornamentals continued to grow.

This research provides preliminary data upon which in situ research should be expanded. Results obtained here may vary in an actual landscape setting due to root growth and branching habits, differences in ET rate in an open environment, and other variables that would be present in a landscape. Additional research is needed to verify WUE between turf and ornamental plants in an urban landscape. Similarly, this research only evaluated one turfgrass and four ornamental species. Results may vary if other species were evaluated.

\section{Literature Cited}

Biran, I., B. Bravdo, I. Bushkin-Harav, and E. Rawitz. 1981. Water consumption and growth rate of 11 turfgrasses as affected by mowing height, irrigation frequency, and soil moisture. Agron. J. 75:85-90.

Broschat, T.K. 1995. Nitrate, phosphate, and potassium leaching from container-grown plants fertilized by several methods. Hortscience 30(1):74-77.

Carrow, R.N. 1996. Drought avoidance characteristics of diverse tall fescue cultivars. Crop Sci. 36:371-377.

Carrow, R.N. 1995. Drought resistance aspects of turfgrasses in the southeast: Evapotranspiration and crop coefficients. Crop Sci. $35: 1685-1690$

Christians, N. 1998. Fundamentals of turfgrass management. Ann Arbor Press, Inc. Chelsa, Mich.

Devitt, D.A., and R.L. Morris. 1989. Growth of common bermudagrass as influenced by plant growth regulators, soil type and nitrogen fertility. J. Environ. Hort. 7:1-8.

Ebdon, J.S. and A.M. Petrovic. 1998. Morphological and growth characteristics of low- and highwater use kentucky bluegrass cultivars. Crop Sci. 38:143-152.

Feldhake, C.M., R.E. Danielson, and J.D. Butler. 1983. Turfgrass evapotranspiration. I. Factors influencing rate in urban environment. Agron. J. 75:824-830.

Gibbens, R. and J. Lenz.1996. Root systems of some Chihuahuan desert plants. J. Arid Environ. 49:221-263.

Green, R.L., K.S. Kim, and J.B.Beard.1990. Effects of flurprimidol, mefluidide, and soil moisture on st. augustinegrass evapotranspiration rate. HortScience 25:439-441.

Huang, B., R.R. Duncan, and R.N. Carrow. 1997. Drought-resistance mechanisms of seven warmseason turfgrasses under surface soil drying: Root aspects. Crop Sci. 37:1863-1869.

Kim, K.S. and J.B. Beard. 1988. Comparative turfgrass evapotranspiration rates and associated plant morphological characteristics. Crop Sci. 28(2):328-331.

Krogman, K.K. 1967.Evapotranspiration by irrigated grass as related to fertilizer. Can. J. Plant Sci. 47:281-287.

Nonami, H., and J.S. Boyer. 1990. Primary events regulating stem growth at low water potentials. Plant Physiol. 94:1601-1609.

Parr, T.W., R.W. Cox, and R.A. Plant. 1984. The effects of cutting height on root distribution and water use of ryegrass turf. J. Sports Turf Res. Inst. 60:45-53.

Peacock, C.H. and A.E. Dudeck. 1984. Physiological responses of st. augustinegrass to irrigation scheduling. Agron. J. 76:275-279.

SAS Institute, Inc.2003. SAS user's guide: Statistics. SAS system version 8. SAS Inst., Inc., Cary, N.C.

Takakura, T., S. Kitade, and E. Goto. 2000. Cooling effect of greenery cover over a building. Energy and Bldg. 31(1):1-6. 